\title{
PENGARUH PEMBERIAN PROBIOTIK BERBEDA PADA PAKAN TERHADAP RETENSI PROTEIN DAN RETENSI LEMAK UDANG VANAME (Litopenaeus vannamei)
}

\section{The Effect of Different Probiotics in Feed to Protein Retention and Fat Retention of Vaname Shrimp (Litopenaeus vannamei)}

\author{
Lukman Arif Kurniawan $^{1 *}$, Muhammad Arief ${ }^{2}$, Abdul Manan ${ }^{2}$, dan Daruti Dinda Nindarwi ${ }^{2}$ \\ ${ }^{1}$ Program Studi Budidaya Perairan, Fakultas Perikanan dan Kelautan, Universitas Airlangga, Surabaya \\ ${ }^{2}$ Departemen Manajemen Kesehatan Ikan dan Budidaya Perairan, Fakultas Perikanan dan Kelautan, Universitas \\ Airlangga, Surabaya \\ *lukmankurniawan94@yahoo.com
}

\begin{abstract}
Abstrak
Permintaan komoditi udang vaname yang cukup tinggi mendorong berkembangnya budidaya udang intensif. Seiring dengan berkembangnya budidaya intensif, maka meningkatkan padat penebaran dan jumlah pakan yang diberikan. Pakan merupakan salah satu unsur penting dalam budidaya yang menunjang pertumbuhan dan kelangsungan hidup. Hal ini menyebabkan pentingnya pakan sehingga perlu penambahan probiotik. Probiotik dapat mengatur lingkungan mikrobial pada usus dan menghasilkan enzim protease dan lipase yang dapat memecah protein dan lemak menjadi molekul lebih sederhana sehingga akan mempermudah proses pencernaan dan penyerapan dalam saluran pencernaan. Tujuan dari penelitian ini adalah untuk mengetahui pengaruh pemberian probiotik berbeda pada pakan terhadap peningkatan retensi protein dan retensi lemak udang vaname (Litopenaeus vannamei). Penelitian ini dilaksanan pada bulan Juni - Juli 2016 di PT. SWK (Surya Windu Kartika) Banyuwangi, Jawa Timur. Metode penelitian yang digunakan adalah metode eksperimental dengan rancangan acak lengkap (RAL) yang terdiri atas empat perlakuan dan lima kali ulangan. Perlakuan yang digunakan adalah pemberian probiotik berbeda yaitu P0 (tanpa pemberian probiotik), P1 (probiotik A), P2 (probiotik B) dan P3 (probiotik C) pada pakan. Analisis data menggunakan statistik. Hasil penelitian menunjukkan bahwa pemberian probiotik berbeda pada pakan memberikan pengaruh yang sangat nyata $(p<0,01)$ terhadap peningkatan retensi protein udang vaname. Rata-rata peningkatan retensi protein terbaik terdapat pada perlakuan P2 (4,55\%) kemudian diikuti oleh perlakauan P3 (3,69\%), P1 (3,55\%) dan P0 (1,20\%). Pemberian probiotik berbeda pada pakan tidak memberikan pengaruh yang nyata $(\mathrm{p}>0,05)$ terhadap peningkatan retensi lemak udang vaname.
\end{abstract}

Kata Kunci : Udang Vaname, Pakan, Probiotik, Retensi Protein, Retensi Lemak

\begin{abstract}
The demand of vaname shrimp is quite high that makes the development of intensively vaname shrimp aquaculture. Along with intensively vaname shrimp aquaculture development, then increase the stocking density and the amount of feed given. Feed is one important thing in aquaculture that supporting the growth and survival rate. That makes how important is the feed, so it is needed to be added of probiotics. Probiotics can control the microbial environment in intestine and produce protease and lypase enzymes to break down the protein and fat become simpler molecules so it will easing the digestive proces and absorption in digestive track. The purposes of this research is to know the effect of diferent probiotics given in feed to increase protein retention and fat retention of vaname shrimp (Litopenaeus vannamei). This research was conducted in June-July 2016 in PT. SWK (Surya Windu Kartika) Banyuwangi, East Java. Methods will be used is experimental method with complete randomized design (CRD) consisting of four treatments are (P0) feed without given probiotic, P1 (probiotic A), P2 (probiotic B) and P3 (probiotic C). Data analysis is statistic. The results showed that addition of probiotics in feed give very significantly effect $(\mathrm{p}<0,01)$ to increase the protein retention of vaname shrimp. The best average increase of protein retention content obtained at P2 (4,55\%) and then followed by treatment P3(3,69\%), P1 (3,55\%) and P0 (1,20\%). Addition of probiotics in feed did not give significant effect $(\mathrm{p}>0,05)$ to increase fat retention of vaname shrimp.
\end{abstract}

Keywords: Vaname Shrimp, Feed, Probiotic, Protein Retention, Fat Retention 


\section{PENDAHULUAN}

Udang vaname (Litopenaeus vannamei) merupakan suatu komoditas perikanan ekonomis penting di Indonesia (Ibrahim dan Ruslaini, 2013). Hal tersebut ditunjukkan dengan meningkatnya produksi budidaya udang vaname pada tahun 2011 sebesar 246.420 ton, tahun 2012 sebesar 251.763 ton dan tahun 2013 sebesar 386.314 ton (Kementerian Kelautan Perikanan, 2015). Berkembangnya spesies ini disebabkan oleh keunggulan yang dimiliki udang vaname, diantaranya memiliki kemampuan adaptasi yang relatif tinggi terhadap perubahan lingkungan seperti perubahan suhu dan salinitas (Adiwidjaya dkk., 2003). Memiliki tingkat responsif yang tinggi terhadapan pakan yang diberikan dan juga memiliki pemasaran yang baik di tingkat internasional (Adiwidjaya dan Sumantri, 2008).

Perkembangan budidaya udang yang semakin pesat menyebabkan pakan buatan berperan vital dan menjadi variabel terbesar dalam biaya produksi yaitu mencapai $50-60 \%$ dari total biaya produksi yang dikeluarkan (Heptarina dkk., 2010). Pakan merupakan salah satu unsur penting dalam kegiatan budidaya yang menunjang pertumbuhan dan kelangsungan hidup ikan budidaya. Hal inilah yang menyebabkan pentingnya pakan sehingga perlu penambahan probiotik untuk memperbaiki nilai nutrisi pakan (Arief dkk., 2014).

Wang et al. (2008) dalam Ahmadi (2012) menjelaskan bahwa bakteri probiotik menghasilkan enzim yang mampu mengurai senyawa kompleks menjadi sederhana sehingga siap digunakan. Dalam meningkatkan nutrisi pakan, bakteri yang terdapat dalam probiotik memiliki mekanisme dalam usus dengan melepas beberapa enzim untuk pencernaan pakan seperti amilase, lipase dan protease. Enzim tersebut yang akan membantu menghidrolisis nutrien pakan (molekul kompleks), seperti memecah karbohidrat, lemak dan protein menjadi molekul yang lebih sederhana sehingga akan mempermudah proses pencer- naan dan penyerapan dalam saluran pencernaan ikan (Putra, 2010).

Udang membutuhkan nutrisi pada pakan untuk pertumbuhan, kesehatan ikan, dan meningkatkan mutu produksi. Salah satu nutrien pakan yang penting yang dibutuhkan udang yaitu protein dan lemak. Protein merupakan sumber energi selain karbohidrat untuk kelangsungan hidup dan pertumbuhan sedangkan lemak merupakan sumber energi terbesar bagi tubuh ikan (Marzuqi, 2013). Banyaknya protein yang tersimpan dalam bentuk jaringan di tubuh ikan dibagi dengan banyaknya protein yang terdapat pada pakan yang dikonsumsi disebut retensi protein. Banyaknya lemak yang tersimpan dalam bentuk jaringan di tubuh ikan dibagi dengan banyaknya lemak pakan yang dikonsumsi disebut retensi lemak (Hariati, 1989).

\section{METODOLOGI \\ Waktu dan Tempat}

Penelitian dilaksanakan di Tambak Bomo A, PT. Surya Windu Kartika (SWK), Banyuwangi, Jawa Timur. Penelitian dilaksanakan pada bulan Juni hingga Juli 2016. Analisis proksimat pakan, analisisis proksimat udang awal dan udang akhir penelitian dilaksanakan di Laboratorium Pakan Ternak Fakultas Kedokteran Hewan, Universitas Airlangga, Surabaya.

\section{Materi Penelitian}

Peralatan Penelitian

Alat yang digunakan dalam penelitian antara lain 20 buah akuarium dengan ukuran $60 \times 35 \times 30 \mathrm{~cm}$, selang aerasi, batu aerasi, blower, timbangan analitik, drum fiber, drum plastik, seser/serok, wadah pakan, sprayer, coolbox, termometer, $\mathrm{pH}$ pen, refraktometer, ammounium test kit, nitrit dan nitrat test kit serta DO meter.

\section{Bahan Penelitian}

Bahan yang digunakan pada penelitian ini yaitu udang vaname memasuki PL (Post Larvae) 50 dengan berat rata-rata 3-4 gram per ekor, pakan 
udang komersial dengan kandungan protein sebesar $31 \%$ berbentuk pelet, air payau 40 liter per akuarium, probiotik dan PBS (Phospate Buffer Saline).

\section{Metode Penelitian}

Metode penelitian yang digunakan dalam penelitian ini adalah metode eksperimental dengan empat perlakuan dan lima kali ulangan. Kusriningrum (2008) menyatakan bahwa eksperimen dapat didefinisikan sebagai suatu tindakan yang dibatasi dengan nyata dan dapat dianalisis hasilnya. Menurut penelitian Wang (2007), pemberian probiotik bubuk dengan dosis $10 \mathrm{~g} / \mathrm{kg}$ pakan menunjukkan pertumbuhan optimal dan meningkatkan kerja aktivitas enzim pencernaan. Penelitian ini bertujuan untuk mengetahui pengaruh pemberian tiga probiotik berbeda pada pakan terhadap retensi protein dan retensi lemak udang vaname. Adapun masing-masing perlakuan tersebut, yaitu :

P0 : pakan komersial tanpa penambahan probiotik (kontrol)

P1 : pakan komersial dengan penambahan probiotik A $10 \mathrm{~g} / \mathrm{kg}$ pakan

P2 : pakan komersial dengan penambahan probiotik B $10 \mathrm{~g} / \mathrm{kg}$ pakan

P3 : pakan komersial dengan penambahan probiotik C $10 \mathrm{~g} / \mathrm{kg}$ pakan

\section{Prosedur Kerja}

Persiapan penelitian dengan membersihkan peralatan yang akan digunakan, akuarium dicuci terlebih dahulu menggunakan deterjen, kemudian dibilas dan didesinfeksi menggunakan kaporit 30 ppm selama 24 jam dan dinetralkan dengan $\mathrm{Na}-$ Thiosulfat 10 ppm untuk memastikan tidak ada lagi sisa kaporit. Akuarium dicuci sampai bersih dan diisi air dari tendon sebanyak 40 liter pada masing-masing akuarium. Setelah dilakukan pengkondisian air akuarium maka dilakukan aerasi selama 1x24 jam untuk meningkatkan oksigen terlarut dan menghilangkan bahan kimia yang tidak diinginkan yang masih ada di dalam akuarium. Kemudian udang vaname yang diambil langsung dari tambak dimasukkan kedalam akuarium.

Pemeliharaan dilakukan selama 30 hari dalam akuarium dengan kepadatan 20 ekor per 40 liter. Udang vaname diadaptasi terlebih dahulu dan diberi pakan kontrol (Ghazali, 2014). Pemberian pakan dilakukan sebanyak lima kali sehari, yaitu pada pukul 07.00, 11.00, 15.00, 19.00 dan 23.00 WIB dengan dosis $7 \%$ pada hari ke 1-7 dan 5\% pada hari ke 8-30. Jumlah pakan yang diberikan berdasarkan pada Feeding Rate (FR) menurut SNI 01-72462006. Kualitas air dikelola dengan cara disipon setiap hari dan dilakukan pergantian air setiap tujuh hari sebanyak 10\% dari total volume akuarium (Noermala, 2012).

Pakan yang digunakan dalam penelitian ini adalah pakan komersial berbentuk pelet. Pakan yang telah diberikan probiotik dianalisis proksimat untuk mengetahui kandungan nutrisinya. Dosis probiotik yang diberikan ke pakan sebesar $10 \mathrm{~g} / \mathrm{kg}$ pakan (Wang, 2007). Sebelum diberikan pada pakan, probiotik yang digunakan ditambah dengan larutan PBS (Phospate Buffer Saline) sebanyak 100 $\mathrm{ml} / \mathrm{kg}$ pakan dan putih telur sebanyak 3\% dari pakan yang diberikan sebagai perekat, setelah itu dikeringanginkan selama 5-15 menit untuk mengurangi kelembapan (Widanarni dkk., 2012).

\section{Parameter Penelitian}

Parameter utama yang diamati adalah retensi protein dan retensi lemak. Parameter pendukung dalam penelitian ini adalah kualitas air. Parameter kualitas air seperti suhu, $\mathrm{pH}$,salinitas dan DO diukur setiap hari sedangkan amonia diukur pada awal, tengah dan akhir penelitian.

\section{Analisis Data}

Data penelitian dianalisis secara statistik. Analisis yang digunakan untuk menjawab rumusan masalah adalah dengan uji ANOVA. Keseluruhan analisis statistik dilakukan dengan program SPSS 16 for windows. Analisis ANOVA digunakan un- 
tuk mengetahui adanya pengaruh pemberian probiotik berbeda pada pakan terhadap retensi protein dan retensi lemak udang vaname (Litopenaeus vannamei).

\section{HASIL DAN PEMBAHASAN Retensi Protein}

Hasil rata-rata retensi protein udang vaname terdapat pada Tabel 1 . Hasil uji statistik menunjukan bahwa pemberian probiotik berbeda pada pakan menghasilkan perbedaan yang sangat nyata $(p<0,01)$ diantara perlakuan terhadap nilai retensi protein udang vaname (Litopenaeus vannamei).

Retensi protein merupakan gambaran dari banyaknya protein yang diberikan, yang dapat diserap, dan dimanfaatkan untuk membangun atau memperbaiki sel-sel tubuh yang sudah rusak, serta dimanfaatkan tubuh ikan bagi metabolisme seharihari (Buwono, 2000). Nilai retensi protein diperoleh dari perbandingan antara banyaknya protein yang tersimpan dalam bentuk jaringan di tubuh ikan dan banyaknya protein pakan yang dikonsumsi.

Tabel 1. Rata-rata retensi protein udang vaname.

\begin{tabular}{lll}
\hline Perlakuan & Retensi Protein $(\%) \pm \mathrm{SD}$ & Transformasi \\
\hline P0 & $1 \%) \pm \mathrm{SD}$ \\
P1 & $1,20^{\mathrm{b}} \pm 1,02$ & $1,23 \pm 0,46$ \\
P2 & $3,55^{\mathrm{a}} \pm 0,82$ & $2,00 \pm 0,20$ \\
P3 & $4,55^{\mathrm{a}} \pm 0,88$ & $2,24 \pm 0,19$ \\
\hline
\end{tabular}

Keterangan: P0 : Tanpa pemberian probiotik (kontrol), P1 : Probiotik A, P2 : Probiotik B, P3 : Probiotik C.Superskrip yang berbeda pada kolom yang sama menunjukkan perbedaan yang sangat nyata $(\mathrm{p}<0,01)$.

Hasil perhitungan ANAVA menunjukkan adanya perbedaan yang sangat nyata $(p<0,01)$ terhadap nilai retensi protein udang vaname. Nilai retensi protein yang rendah didapat pada perlakuan $\mathrm{P0}$ $(1,20 \%)$ yang berbeda nyata dengan perlakuan P1 (3,55\%), P2 (4,55\%) dan P3 (3,69\%). Rendahnya nilai retensi protein dikarenakan pada perlakuan P0 (kontrol) merupakan pemberian pakan tanpa penambahan probiotik, sehingga ketersediaan bakteri penghasil enzim protease pada saluran pencernaan terbatas. Keterbatasan ini menyebabkan kurangnya penyerapan protein pakan yang tidak dibantu oleh adanya bakteri probiotik sehingga penyerapan protein pakan menjadi tidak optimal. Hal ini sesuai dengan pernyataan Handajani (2006) yang menyatakan bahwa peran mikroba probiotik dalam pakan ikan mampu memecah unsur nutrisi yang lebih sederhana, sehingga membantu proses pencernaan dan penyerapan nutrisi yang lebih baik.
Hasil penelitian menunjukkan adanya kecenderungan peningkatan peresentase retensi protein seiring dengan konsentrasi bakteri dari probiotik yang digunakan untuk perlakuan. Kandungan retensi protein yang tinggi pada P2 (Probiotik B) ini diduga karena pada probiotik B memiliki konsentrasi bakteri paling tinggi yaitu 9,8 x $10^{6}$ CFU dibandingkan dengan konsentrasi bakteri pada probiotik A dan Probiotik C. Perbedaan jumlah bakteri yang terkandung dalam probiotik dapat mempengaruhi penyerapan nutrisi udang vaname karena semakin banyak populasi bakteri Bacillus dan Lactobacillus yang ada dalam saluran pencernaan akan meningkatkan ketersediaan nutrien yang siap diserap dalam saluran pencernaan melalui hidrolisis protein menjadi senyawa yang lebih sederhana yaitu asam amino, sehingga metabolisme menjadi lebih mudah karena penyerapan protein terbantu oleh adanya enzim protease. Hal ini sesuai dengan pernyataan (Setiawati dkk., 2013) bahwa enzim yang disekresikan jumlahnya me- 
ningkat sesuai dengan jumlah probiotik yang ada dalam saluran pencernaan, yang akan meningkatkan jumlah pakan yang dicerna. Peningkatan daya cerna ini berarti semakin tingginya nutrien yang tersedia untuk diserap oleh tubuh.

\section{Retensi Lemak}

Hasil rata-rata retensi lemak udang vaname terdapat pada Tabel 2. Hasil uji statistik menunjukan bahwa pemberian probiotik berbeda pada pakan tidak memberikan perbedaan yang nyata $(p>0,05)$ diantara perlakuan terhadap nilai retensi lemak udang vaname (Litopenaeus vannamei).

Retensi lemak menggambarkan kemampuan ikan dalam menyimpan dan memanfaatkan lemak pakan. Nilai retensi lemak diperoleh dari perbandingan antara banyaknya lemak yang tersimpan dalam bentuk jaringan di tubuh ikan dan banyaknya lemak pakan yang dikonsumsi. Kecernaan lemak bervariasi tergantung jumlah dalam pakan, tipe dari lemak, suhu air, derajat kejenuhan lemak dan panjang rantai karbonnya (Fahy et al., 2005).

Tabel 2. Rata-rata retensi lemak udang vaname.

\begin{tabular}{ccc}
\hline Perlakuan & Retensi Lemak $(\%) \pm \mathrm{SD}$ & Transformasi $\sqrt{\mathrm{y}(\%) \pm \mathrm{SD}}$ \\
\hline P0 & $4,83 \pm 1,76$ & $2,28 \pm 0,38$ \\
P1 & $5,30 \pm 1,06$ & $2,40 \pm 0,22$ \\
P2 & $5,42 \pm 2,53$ & $2,39 \pm 0,49$ \\
P3 & $2,93 \pm 0,93$ & $1,84 \pm 0,25$
\end{tabular}

Keterangan: P0 : Tanpa pemberian probiotik (kontrol), P1 : Probiotik A, P2 : Probiotik B, P3 : Probiotik C. Superskrip yang sama pada kolom yang sama menunjukkan tidak ada perbedaan yang nyata $(\mathrm{p}>0,05)$.

Hasil perhitungan ANAVA menunjukkan bahwa pemberian pakan dengan probiotik berbeda tidak memberikan perbedaan yang nyata terhadap nilai retensi lemak udang vaname. Hal ini disebabkan karena pada perlakuan lemak yang telah dihidrolisis diserap dan digunakan sebagai sumber energi yang menyebabkan rendahnya lemak yang terkandung dalam daging udang, sehingga memberikan nilai retensi lemak yang rendah pada udang vaname. Lipid yang terdapat pada pakan akan dicerna dan diserap pada organ pencernaan dan ditransport menuju sel untuk disimpan atau digunakan (Plascencia et al., 2000).

Analisis proksimat menunjukkan kadar lemak rata-rata yang dapat disimpan pada udang vaname hasil perlakuan $\mathrm{P0}$ (kontrol) 3,04\%, P1 (Probiotik B) 2,63\%, P2 (Probiotik C) 2,21\% dan P3 (Probiotik C) $2,16 \%$. Rendahnya kandungan lemak pada daging udang vaname percobaan dapat dijadikan kesimpulan bahwa, lemak yang telah diserap dari proses pencernaan digunakan oleh udang percobaan sebagai sumber energi dan proses metabolisme lain. Lipid yang tersimpan ditransportasikan pada beberapa organ dan jaringan selama waktu tertentu seperti pada stadia premolt (Priya et al., 2013). Lemak dari pakan digunakan untuk energi dan memaksimalkan protein untuk proses partumbuhan (Boonyaratpalin, 1996).

Pada hasil perlakuan pemberian probiotik dapat menguraikan lemak menjadi asam lemak. Hal ini sesuai dengan pernyataan Fardiaz (1992) bahwa Bacillus dan Lactobacillus (Adriani dkk., 2008) dapat mensekresikan enzim lipase. Enzim lipase menghidrolisis lemak menjadi asam lemak sehingga mempermudah penyerapan lemak oleh tubuh udang. Lemak dari pakan digunakan untuk energi dan memaksimalkan protein untuk proses partumbuhan. Hal ini sesuai dengan pernyataan (Komariyah, 2009) bahwa penggunaan lemak sebagai "protein sparring effect" yaitu lemak mempunyai fungsi untuk 
menggantikan protein sebagai sumber energi, sehingga penggunaan protein dapat dioptimalkan untuk pertumbuhan

\section{Kualitas Air}

Kualitas air diukur untuk melengkapi data utama. Parameter kualitas air seperti suhu, $\mathrm{pH}, \mathrm{DO}$, salinitas dilakukan sehari 2 kali yaitu pada pagi dan sore hari. Data rata-rata kualitas air selama 30 hari penelitian dapat dilihat pada Tabel 3.
Nilai kualitas air yang juga diukur selama penelitian adalah amonia. Data rata-rata pengukuran amonia pada awal, tengah dan akhir penelitian setiap perlakuan dapat dilihat pada Tabel 4. Nilai amonia cenderung mengalami peningkatan dari awal penelitian hingga akhir penelitian, pada awal penelitian nilai amonia adalah $0,05 \mathrm{mg} / \mathrm{l}$ dan meningkat menjadi $0,1 \mathrm{mg} / \mathrm{l}$ di akhir penelitian.

Tabel 3. Nilai kualitas air selama 30 hari penelitian

\begin{tabular}{cccccc}
\hline \multirow{2}{*}{ Perlakuan } & \multicolumn{4}{c}{ Parameter Kualitas Air } \\
\cline { 3 - 6 } & & Suhu $\left({ }^{0} \mathrm{C}\right)$ & $\mathrm{pH}$ & Salinitas (ppt) & DO (mg/l) \\
\hline \multirow{2}{*}{ P0 } & Pagi & $26,1-29,8$ & $7,0-7,9$ & $29-32$ & $3,86-5,90$ \\
& Sore & $29,2-31,3$ & $7,1-7,8$ & $29-31$ & $4,76-5,84$ \\
\hline \multirow{2}{*}{ P1 } & Pagi & $26,6-28,7$ & $7,0-7,8$ & $29-31$ & $4,10-6,00$ \\
& Sore & $28,2-30,5$ & $6,7-7,7$ & $29-31$ & $5,52-5,89$ \\
\hline \multirow{2}{*}{ P2 } & Pagi & $26,8-29,2$ & $6,9-7,9$ & $29-31$ & $4,10-5,90$ \\
& Sore & $29,5-30,7$ & $7,0-7,8$ & $30-31$ & $5,34-5,98$ \\
\hline \multirow{2}{*}{ P3 } & Pagi & $26,1-29,1$ & $7,1-7,9$ & $28-31$ & $4,10-5,80$ \\
& Sore & $28,2-30,8$ & $6,9-7,9$ & $29-30$ & $5,25-5,80$ \\
\hline
\end{tabular}

Tabel 4. Rata-rata nilai amonia (mg/l)

\begin{tabular}{cccc}
\hline \multirow{2}{*}{ Perlakuan } & \multicolumn{3}{c}{ Hari Ke } \\
\cline { 2 - 4 } & Awal & Tengah & Akhir \\
\hline P0 & $0,01 \mathrm{mg} / \mathrm{l}$ & $0,05 \mathrm{mg} / \mathrm{l}$ & $0,1 \mathrm{mg} / \mathrm{l}$ \\
P1 & $0,01 \mathrm{mg} / \mathrm{l}$ & $0,02 \mathrm{mg} / \mathrm{l}$ & $0,07 \mathrm{mg} / \mathrm{l}$ \\
P2 & $0,01 \mathrm{mg} / \mathrm{l}$ & $0,02 \mathrm{mg} / \mathrm{l}$ & $0,07 \mathrm{mg} / \mathrm{l}$ \\
P3 & $0,01 \mathrm{mg} / \mathrm{l}$ & $0,02 \mathrm{mg} / \mathrm{l}$ & $0,07 \mathrm{mg} / \mathrm{l}$ \\
\hline
\end{tabular}

Kualitas air merupakan faktor penting dalam menunjang kelangsungan hidup budidaya. Kualitas air yang diukur pada penelitian ini meliputi suhu, $\mathrm{pH}$, salinitas, oksigen terlarut (DO) dan amonia. Hasil pengukuran suhu selama penelitian terdapat perbedaan dimana suhu pada pagi hari lebih rendah dibanding suhu pada sore hari, hal ini dipengaruhi oleh suhu di lingkungan sekitar. Nilai rentang suhu selama perlakuan di pagi hari yaitu 26- $29^{0} \mathrm{C}$, sedangkan suhu pada sore hari yaitu $28-31^{0} \mathrm{C}$. Nilai ini menunjukkan suhu air berada dalam kondisi yang optimal unutk pertumbuhan udang vaname.
Menurut Suprapto (2005) bahwa suhu optimal untuk budidaya udang vaname berkisar $27-32^{0} \mathrm{C}$.

Hasil pengukuran $\mathrm{pH}$ air selama penelitian berkisar 6,7 - 7,9. Kondisi $\mathrm{pH}$ air yang optimal untuk budidaya vaname berkisar 7,3 - 8,5 (Suprapto, 2005), namun udang vaname memiliki toleransi $\mathrm{pH}$ 6,5 9 (Wyban and Sweeny, 1991). Nilai pH pada perlakuan P1 lebih rendah disebabkan karena aktivitas bakteri Lactobacillus sp. yang terdapat pada probiotik A. Hal ini sesuai dengan pendapat Delgado et al. (2001) dalam Arief dkk. (2014) bahwa Lactobacillus akan mengubah karbohidrat 
menjadi asam laktat, kemudian asam laktat dapat menciptakan suasana $\mathrm{pH}$ yang lebih rendah. Nilai salinitas selama penelitian berkisar 27 - 32 ppt. Nilai ini menunjukkan salinitas air masih berada dalam kisaran yang dapat ditoleransi oleh udang vaname dikarenakan udang vaname mampu hidup pada salinitas yang luas (euryhaline). Hal ini sesuai dengan pernyataan Saoud et al. (2003) bahwa udang vaname mampu hidup pada kisaran salinitas lebar yaitu $0,5-60$ ppt.

Hasil pengukuran DO setiap perlakuan selama 30 hari penelitian yaitu 3,90 - 5,90 mg/. Nilai DO pada tiap perlakuan antara pagi dan sore tidak menunjukkan perbedaan yang signifikan, hal ini dipengaruhi penambahan aerator pada tiap perlakuan sehingga nilai DO tetap terkontrol pada nilai optimal. Nilai ini tergolong baik bagi kelangsung hidup udang vaname, sesuai dengan pernyataan Adiwijaya et al. (2003) bahwa kisaran optimal DO selama masa pemeliharaan berkisar 3,5 - 7,5 mg/l. Kandungan amonia dapat mempengaruhi kelulushidupan udang vaname. Kandungan amonia melebihi ambang batas dapat menjadi stressor pada udang vaname (Erlangga 2012). Hasil pengukuran amonia pada masing-masing perlakuan masih dalam ambang batas yang normal 0,01-0,1 $\mathrm{mg} / \mathrm{l}$. Hal ini sesuai dengan pernyataan Suyanto dan Mujiman (2004) bahwa kadar amonia yang baik untuk budidaya udang kurang dari 0,1 mg/l.

\section{KESIMPULAN DAN SARAN Kesimpulan}

Berdasarkan hasil analisis dan pembahasan dalam penelitian ini, dapat disimpulkan bahwa pemberian probiotik berbeda pada pakan memberikan pengaruh yang nyata terhadap peningkatan kandungan retensi protein udang vaname, tetapi tidak memberikan pengaruh yang nyata terhadap peningkatan retensi lemak udang vaname.

\section{Saran}

Berdasarkan hasil penelitian yang telah dilakukan, disarankan untuk melakukan penelitian lebih lanjutdengan dosis yang berbeda dan periode pemberian yang tepat untuk meningkatkan retensi protein dan retensi lemak udang vaname (Litopenaeus vannamei).

\section{DAFTAR PUSTAKA}

Adiwidjaya, D., S. P. Raharjo, E. Sutiknodan S. Subiyanto. 2003. Petunjuk Teknis Budidaya Vanname Sistem Tertutup yang Ramah Lingkungan. Departemen Kelautan dan Perikanan Direktorat Jenderal Perikanan Budidaya, Balai Besar Pengembangan Budidaya Air Payau. 29 hal.

Adiwidjaya, D. dan S. I. Sumantri. 2008. Penerapan Teknologi Budidaya Udang Vanname (L. Vannamei) Semi-Intensif Pada Lokasi Tambak Salinitas Tinggi . Media Budidaya Air Payau Perekayasaan No. 7. 19 hal.

Adriani, L., N. Indrayati, U. H. Tanuwiria dan N. Maysari. 2008. Aktivitas Lactobacillus acidophilus dan Bifidobacterium Terhadap Kualitas Yoghurt dan Penghambatannya pada Helicobacter pylori. Jurnal Bionatura X (2): 129-140.

Ahmadi, H., Iskandar., N. Kurniawati. 2012. Pemberian Probiotik dalam Pakan Terhadap Pertumbuhan Lele Sangkuriang (Clarias graprienus) pada Pendederan II. 3(4): 99-107.

Arief, M., N. Fitriani dan S. Subekti. 2014. Pengaruh Pemberian Probiotik Berbeda Pada Pakan Komersial Terhadap Pertumbuhan dan Efisiensi Pakan Ikan Lele Sanglariang (Clarias sp.). Jurnal Ilmiah Perikanan dan Kelautan 6(1) : 4952.

Boonyaratpalin, M. 1996. Nutritional Requirements of Commercially Important Shrimp in the Tropics. Proceedings of the National Semi- 
nar Workshop on Fish Nutrition and Feeds. SEAFDEC Aquaculture Department, Iloilo, Philippines.

Buwono, I. D. 2000. Kebutuhan Asam Amino Esensial dalam Ransum Pakan Ikan. Penerbit Kanisius. Yogyakarta. Hal 31-36.

Erlangga, E. 2012. Budidaya Udang Vannamei Secara Intensif. Pustaka Agro Mandiri. Tangerang Selatan. 128 hal.

Fahy, E., S. Subramaniam, H. A. Brown., C. K. Glass, A. H. Merill and R. C. Murphy. 2005. A Comprehensive Classication for Lipids. Eur J Lipid Sci Technol 2005: 337-364.

Fardiaz, S. 1992. MikrobiologiPangan 1. Jakarta: GramediaPustakaUtama.

Ghazaly, G. A. F. 2014. Aplikasi Probiotik, Prebiotik dan Sinbiotik Melalui Pakan pada Udang Vaname (Litopenaeus vannamei) yang Dipelihara pada Jaring Hapa. Skripsi. Departemen Budidaya Perairan Fakultas Perikanan dan Ilmu Kelautan Institut Pertanian Bogor. Bogor.

Handajani H. 2006. Pemanfaatan tepung Azolla sebagai penyusun pakan ikan terhadap pertumbuhan dan daya cerna ikan nila GIFT. Malang: Universitas Muhammadiyah Malang.

Hartiati, A.M. 1989. Makanan Ikan. Diktat Kuliah Universitas Brawijaya. Malang. 155hal.

Hardiwiyoto, S. 1993. Teknologi Pengolahan Hasil Perikanan. Fakultas Teknologi Pertanian UGM. Liberty. Yogyakarta.

Heptarina, D., M. A. Supriyadi, I. Mokoginta dan D. Yaniharto. 2010. Pengaruh Pemberian Pakan dengan Kadar Protein Berbeda Terhadap Pertumbuhan Yuwana Udang Putih Litopenaeus vannamei. Prosiding Forum Inovasi Teknologi Akuakultur. 6 hal.

Ibrahim, N dan Ruslaini. 2013. Pertumbuhan dan Sintasan Larva Udang
Vaname (Litopenaeus vannamei) melalui Subtitusi Tepung Ikan dengan Tepung Usus Ayam. Jurnal Mina Laut Indonesia, 1(1) : 93-103. Kementerian Kelautan dan Perikanan. 2015. Data Statistik Tahunan Produksi Perikanan Budidaya. http://www.djpb.kkp.go.id/. Diakses tanggal 25 September 2015.

Komariyah dan A. I. Setiawan. 2009. Pengaruh Penambahan Berbagai Dosis Minyak Ikan yang Berbeda pada Pakan Terhadap Pertumbuhan Benih Ikan Patin (Pangasius

Marzuqi, M. dan D. N. Anjusary. 2013. Kecernaan Nutrien Pakan dengan Kadar Protein dan Lemak Berbeda pada Juvenil Ikan Kerapu Pasir (Epinephelus corallicola). Jurnal Ilmu dan Teknologi Kelautan Tropis. Vol 5 (2) : 311-323.

Noermala I. J. 2012. Pemberian Probiotik, Prebiotik dan Sinbiotik untuk Pengendalian Koinfeksi Bakteri Vibrio harveyi pada Udang Vaname (Litopenaeus vannamei). Tesis. Sekolah Pascasarjana Institut Pertanian Bogor. Bogor.

Plascencia, G. Y., F. V. Albores and I. H. Ciaparra. 2000. Penaeid Shrimp Hemolymph Lipoproteins. Aquaculture 191: 177-189.

Priya, E. R., K. L. J. Kala, S. Ravichandran and M. Chandran. 2013. Variation of Lipid Concentration in Some Edible Crabs. Journal of Fish and Marine Sciences 5 (1): 110-112.

Putra, A. N. 2010. Kajian Probiotik, Prebiotik dan Sinbiotik untuk Meningkatkan Kinerja Pertumbuhan Ikan Nila (Oreochromis niloticus). Tesis. Program Pasca Sarjana. Institut Pertanian Bogor. Bogor. 91 hal.

Saoud, I. P., D. A. Davis and D. B. Rouse. 2003. Suitability Studies of Inland Well Waters for Litopenaeus vannamei Culture. Aquaculture, 217: 373-383

Diterima/submitted:19 September 2016

Disetujui/accepted:25 Desember 2016 
Setiawati, J. E., Tarsim, Y. T. Adiputra dan S. Hudaidah. 2013. Pengaruh Penambahan Probiotik pada Pakan dengan Dosis Berbeda Terhadap Pertumbuhan, Kelulushidupan, Efisiensi Pakan dan Retensi Protein Ikan Patin (Pangasius hypophthalmus). Jurnal Rekayasa dan Teknologi Budidaya Perairan. Vol 1 (2) : 151-162.

SNI (Standar Nasional Indonesia). 2006. Produksi Udang Vaname L. vannamei di Tambak dengan Teknologi Intensif. Badan Standarisasi Nasional.

Suprapto. 2005. Petunjuk teknis budidaya udang vannamei (Litopenaeus vannamei). CV Biotirta. Bandar Lampung. 25 hal.

Suyanto, S.R. dan A. Mujiman. 2004. Budiaya Udang Windu. Jakarta: Penebar Swadaya.

Wang, Y. B. 2007. Effect of Probiotics on Growth Perfomance and Digestive Enzyme Activity of The Shrimp Penaeus vannamei. J. Aquaculture. 269(4): 254-264.

Widanarni, P. Widagdo dan D. Wahjuningrum. 2012. Aplikasi Probiotik, Prebiotik dan Sinbiotik Melalui Pakan pada Udang Vaname (Litopenaeus vannamei) yang Diinfeksi Bakteri Vibriyo harveyi. Jurnal Akuakultur Indonesia. XI (1) : 51-63.

Wyban, J.A and Sweeny, J.N. 1991. Intensive Shrimp Production Technology. The Oceanic Institute Makapuu Point. Honolulu, Hawai USA. 158 hal. 